\title{
Microsomal Cytochrome P-450 Enzyme Damage in Cultured Leydig Cells: Relation to Steroidogenic Desensitization $^{a}$
}

\author{
PATRICK G. QUINN ${ }^{b}$ and ANITA H. PAYNE \\ Departments of Biological Chemistry and Obstetrics \\ and Gynecology \\ Reproductive Endocrinology Program \\ The University of Michigan \\ Ann Arbor, Michigan 48109
}

It is well established that treatment of animals with a single high dose of LH or hCG results in steroidogenic desensitization of Leydig cells. ${ }^{1,2}$ Desensitized Leydig cells exhibit a decreased capacity to produce testosterone in response to subsequent stimulation with gonadotropins or cAMP analogues, and have decreased activities of the microsomal P-450 enzymes, $17 \alpha$-hydroxylase, and $\mathrm{C}_{17-20}$ lyase. The present study provides evidence that the decreases in microsomal P450 activities are caused by oxygen-derived, free-radical damage of the enzymes, and, furthermore, that the decrease in microsomal P-450 activities are not the primary cause of the decrease in testosterone-producing capacity observed in desensitized Leydig cells.

Primary cultures of purified, adult mouse Leydig cells were maintained in serum-free medium at $32^{\circ} \mathrm{C}$, in a humidified atmosphere of $19 \% \mathrm{O}_{2}(95 \%$ air $/ 5 \%$ $\mathrm{CO}_{2}$ ) or $1 \% \mathrm{O}_{2}$, in the presence and absence of the antioxidant dimethyl sulfoxide. The culture medium was changed daily and the activities of microsomal enzymes were determined by quantifying the conversion of ${ }^{3} \mathrm{H}$-substrate to ${ }^{3} \mathrm{H}$-products during a $1 \mathrm{hr}$ incubation at $37^{\circ} \mathrm{C}$, in an atmosphere of $19 \% \mathrm{O}_{2}$. The maximal capacity to produce testosterone was determined by incubating replicate cultures with $1 \mathrm{mM} 8-\mathrm{Br}-\mathrm{cAMP}$ for a $3 \mathrm{hr}$ period and measuring testosterone in the medium by radioimmunoassay.

$1 \mathrm{mM} 8-\mathrm{Br}-\mathrm{cAMP}$ was added to half of the Leydig cells, during the initial $24 \mathrm{hr}$ of culture only, to induce steroidogenic desensitization. The other half served as controls. Testosterone production by desensitized Leydig cells was 15 -fold and threefold greater than that of controls on days one and two of culture, respectively. The addition of dimethyl sulfoxide to the culture medium and/or reduction of the oxygen tension had no effect on testosterone production by control or desensitized Leydig cells.

The data presented in TABLE 1 demonstrate that, when control Leydig cell cultures are incubated in $19 \% \mathrm{O}_{2}$, the microsomal P-450 activities, $17 \alpha$-hydroxylase and $\mathrm{C}_{17-20}$ lyase, are stable during the first $24 \mathrm{hr}$ but decrease markedly by 48

"This study was supported by National Institutes of Health Grant HD-08538. Patrick G. Quinn is supported in part by National Institutes of Health Training Grant HD-07048.

${ }^{b}$ Address correspondence to: Patrick G. Quinn, Steroid Research Unit, L 1221 Women's Hospital, The University of Michigan, Ann Arbor, MI 48109. 


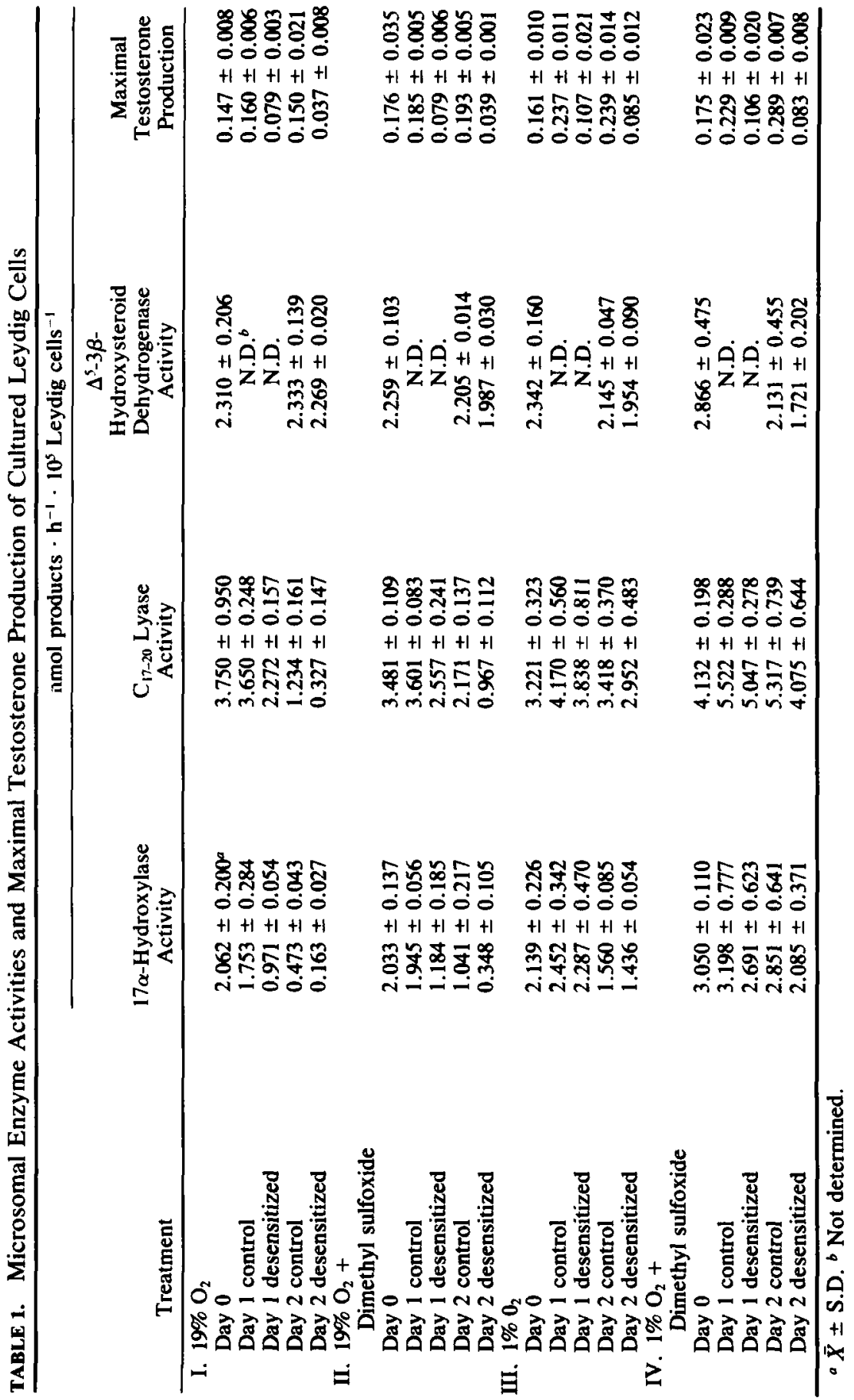


hr. This decline in P-450 activities was partially prevented by addition of the antioxidant dimethyl sulfoxide to the medium or by reduction of the oxygen tension. The combined effects of these treatments were synergistic in preserving the P-450 activities of control Leydig cells. In contrast, the P-450 activities of desensitized Leydig cells maintained at $19 \% \mathrm{O}_{2}$ were reduced to 50 and $33 \%$ of control values at 24 and $48 \mathrm{hr}$, respectively. However, when Leydig cells were cultured in an atmosphere of $1 \% \mathrm{O}_{2}$, the cAMP-induced decrease in the P-450 activities was essentially prevented. The activity of $\Delta^{5}-3 \beta$-hydroxysteroid dehydrogenase-isomerase, a microsomal enzyme that is not P-450-dependent, was stable in both control and desensitized Leydig cells during the $48 \mathrm{hr}$ culture period, indicating that the decrease in microsomal P-450 activities was specific and not due to damage of the cells and/or the smooth endoplasmic reticulum. These data are consistent with the hypothesis that oxygen-mediated damage is responsible for the time-dependent decrease in $17 \alpha$-hydroxylase and $\mathrm{C}_{17-20}$ lyase activities of control Leydig cells, and is the mechanism by which these activities are further decreased in desensitized Leydig cells. The large and rapid reduction of hydroxylase and lyase activities of desensitized Leydig cells at $19 \% \mathrm{O}_{2}$ is consistent with the model described by Hornsby for inactivation of the adrenal P. 450 enzyme, $11 \beta$-hydroxylase, by the product, cortisol. ${ }^{3}$ In this model, interaction of products (pseudosubstrates) with the enzyme leads to release of damaging free radicals from the $\mathrm{P}-450$-pseudosubstrate complex, due to the inability of the steroid product to be hydroxylated. In this regard, it should be noted that during the desensitization process, Leydig cells are exposed to high concentrations $(\sim 2 \mu \mathrm{M})$ of the product, testosterone. Recent results, which indicate that a $24 \mathrm{hr}$ incubation of Leydig cells with high $(2 \mu \mathrm{M})$ but not low $(0.2 \mu \mathrm{M})$ concentrations of testosterone causes the same extent of decrease in $\mathrm{P}-450$ activities as incubation with cAMP, and that this decrease is prevented by reduction of the oxygen tension, support the hypothesis that decreases in microsomal P-450 activities of desensitized Leydig cells are caused by steroid pseudosubstrate-induced, oxygen-derived, free-radical damage of these P-450 enzymes.

The capacity of control Leydig cells to produce testosterone in response to cAMP was not diminished at any time or under any culture conditions tested, even though P-450 activities of cultures maintained at $19 \% \mathrm{O}_{2}$ had decreased by $75 \%$ after $48 \mathrm{hr}$. In contrast, the capacity of desensitized Leydig cells had decreased by $50 \%$ at $24 \mathrm{hr}$ under all culture conditions, in spite of the fact that Leydig cells maintained at $1 \% \mathrm{O}_{2}$ did not exhibit decreased $\mathrm{P}-450$ activity at this time. Thus, the decrease in maximal capacity for testosterone production of desensitized Leydig cells cannot be attributed to the decrease in $17 \alpha$-hydroxylase and $C_{17-20}$ lyase activities and must be caused by other factors, such as a decrease in cholesterol side-chain cleavage activity ${ }^{4}$ or depletion of cholesterol stores. ${ }^{5,6}$

\section{REFERENCES}

1. Cigorraga, S. B., M. L. Dufau \& K. J. Catt. 1978. J. Biol. Chem. 253: 4297-4304.

2. O'shaughnessy, P. J. \& A. H. Payne. 1982. J. Biol. Chem. 257: 11503-11509.

3. Hornsby, P. J. 1980. J. Biol. Chem. 255: 4020-4027.

4. Luketich, J. D., M. H. Melner, F. P. Guengerich \& D. Puett. 1983. Biochem. Biophys. Res. Commun. 111: 424-429.

5. Quinn, P. G., L. J. Dombrausky, Y-D. I. Chen \& A. H. Payne. 1981. Endocrinology 109: $1790-1792$.

6. Freeman, D. A. \& M. Ascolı. 1982. Proc. Natl. Acad. Sci. USA 79: 7796-7800. 